\title{
Monoclonal antibody and lectin probes recognize developmental and sporogonic stages of PKX, the causative agent of proliferative kidney disease in European and North American salmonid fish
}

\author{
M. Marin de Mateo ${ }^{1}$, A. Adams ${ }^{2}$, R. H. Richards ${ }^{2}$, M. Castagnaro ${ }^{1}$, R. P. Hedrick ${ }^{3, *}$ \\ ${ }^{1}$ Dipartmento di Patologia Animale, Facoltá di Medicina Veterinaria, Via Nizza 52, I-10126, Torino, Italy \\ ${ }^{2}$ Institute of Aquaculture, University of Stirling, Stirling FK9 4LA, Scotland, UK \\ ${ }^{3}$ Department of Medicine, School of Veterinary Medicine, University of California, Davis, California 95616, USA
}

\begin{abstract}
The lectin GS-I (Griffonia simplicifolia agglutinin-I) and a recently developed monoclonal antibody (Mab12) both recognized extrasporogonic (interstitial) and sporogonic (intraluminal) stages of the PKX myxosporean causing proliferative kidney disease (PKD) in salmonid fish. In histochemical and immunostains the lectin and antibody recognized PKX from North American and European salmonids including Atlantic salmon Salmo salar, chinook salmon Oncorhynchus tshawytscha, coho salmon Oncorhynchus kisutch, brown trout Salmo trutta, and grayling Thymallus thymallus. Although the specific structures recognized by the lectin and Mab12 were not determined, double fluorescent staining techniques showed similar staining patterns with extrasporogonic or interstitial stages of the PKX myxosporean. An apparent inhibition between the lectin and Mab12 in these double stains suggests that they recognize similar structures of the parasite. Sporogonic stages of PKX, some containing polar capsules, were detected with the lectin and Mab12 stains in fish with typical extrasporogonic (interstitial) PKX providing further confirmation of the relatedness of these stages. Both the lectin and Mab12 provide useful tools for further study of the epidemiology of the PKX myxosporean, for future development of tests to detect anti-parasite antibodies in fish serum and for the identification of potential immunogens for vaccination of trout.
\end{abstract}

\section{INTRODUCTION}

Proliferative kidney disease (PKD) is considered to be the most serious systemic protozoal infection in rainbow trout Oncorhynchus mykiss in Europe (Ghittino et al. 1977, Clifton-Hadley et al. 1984) and causes significant losses in rainbow trout and Pacific salmon in North America (Hedrick et al. 1984a, b, 1985, 1986a, b). The disease affects several salmonid species in Europe and North America including Atlantic salmon Salmo salar (Ellis et al. 1982), chinook salmon Oncorhynchus tshawytscha, coho salmon Oncorhynchus kisutch (Hedrick et al. 1984a, b), artic char Salvelinus alpinus (Brown et al. 1991, Bucke et al. 1991), brown trout Salmo trutta (Roberts 1978, Wooten \& McVicar 1982) and grayling Thymallus thymallus (Seagrave et al.

- Addressee for correspondence
1981). The only nonsalmonid reported to suffer PKD is pike Esox lucius (Seagrave et al. 1981, Bucke et al. 1991).

PKD is caused by a presently unclassified myxosporean (PKX) with similarities to Sphaerospora spp. as found in other species of fish (Kent 1985, Kent \& Hedrick 1985a, 1986, Fischer-Scherl et al. 1986, Feist \& Bucke 1987, Hedrick et al. 1988, 1991, von Odening et al. 1988, Rafferty \& Mulcahy 1988). Developmental stages of the myxosporean can be detected in stained tissue sections or imprints from several organs but principally the kidney of fish with clinical signs of PKD (Clifton-Hadley et al. 1983, Klontz \& Chacko 1983, Hedrick et al. 1986a). Tissue sections stained with hematoxylin and eosin allow visualization of typical extrasporogonic stages and early sporogonic forms of the myxosporean. While generally effective and used for confirmatory diagnoses, this histological method is not based on a specific binding or recognition of PKX 
but instead detects its somewhat unique morphology and slightly different staining pattern (Ferguson \& Needham 1978).

Specific staining procedures for the PKX myxosporean in rainbow trout kidney have recently been reported by Castagnaro et al. (1991) and Marin de Mateo et al. (1991). Paraffin-embedded sections were treated with a biotinylated GS-I (Griffonia simplicifolia agglutinin-I), a lectin recognizing methyl- $\alpha$-D-galactopyranosides in glycoconjugates present on PKX. Avidin-horse radish peroxidase in the presence of the enzyme substrate 3'3-diaminobenzidine tetrahydrochloride-hydrogen peroxide was then added to visualize the lectin bound to the parasite (Castagnaro et al. 1991, Marin de Mateo et al. 1991). An adaptation of the lectin stain for rapid diagnosis has also been described by Hedrick et al. (1992). The latter technique employs biotinylated GS-I and avidin-fluorescein to detect PKX in fixed kidney imprints with the entire procedure requiring only 2 to $3 \mathrm{~h}$. This fluorescence test has been shown to detect early infections and it removes the subjectivity in interpreting results making it an attractive alternative to examination of fresh preparations or traditional stains on tissue sections or imprints.

Two monoclonal antibodies have recently been produced against PKX cells by Adams et al. (1992). One of these antibodies (Mab12) has shown no cross reactivity with other myxosporeans tested to date (authors' unpubl. data) and makes it a suitable reagent for confirmatory diagnoses for PKX in immunohistochemical tests. This is the second report of a monoclonal antibody produced against a myxosporean parasite. Bartholomew et al. (1989) were the first to develop monoclonal antibodies against Ceratomyxa shasta.

In this paper we describe the application of this new monoclonal antibody (Mab12) and the GS-I lectin for detecting antigens or glycoconjugates on both extrasporogonic and sporogonic stages of PKX. In addition, the efficacy of these procedures were tested on several species of fish from diverse geographical regions in an effort to examine potential strain differences of the PKX myxosporean.

\section{MATERIALS AND METHODS}

Tissue samples. Kidneys from fish infected with PKX and control uninfected tissues were obtained from several salmonid species from different geographical regions. These included: rainbow trout from Italy, the United Kingdom, France and the USA; Atlantic salmon from Ireland and Scotland; brown trout and grayling from the United Kingdom and Pacific salmon (chinook and coho) from North America. All kidney tissues were fixed with either $10 \%$ neutral buffered formalin (Euro- pean samples) or Davidson's solution (North American samples). In general, tissues were fixed for $24 \mathrm{~h}$, dehydrated through an ethanol series, embedded in paraffin and then sectioned at $5 \mu \mathrm{m}$. APES (3-amino propyltriethoxylane) was used to increase the adherence and prevent separation of tissue sections during staining (Maddox \& Jenkins 1987).

Lectin histochemistry. A histochemical staining procedure using GS-I biotinylated lectin as descibed by Castagnaro et al. (1991) was followed. PKD and uninfected paraffin-embedded kidney sections were deparaffinized and hydrated and endogenous peroxidase activity was blocked by incubating tissue sections in $3 \%$ hydrogen peroxide in water solution at $40^{\circ} \mathrm{C}$ for $10 \mathrm{~min}$. After washing in $0.2 \mathrm{M}$ phosphate buffer saline $\mathrm{pH} 6.8$ (PBS), tissue sections were immersed in $0.1 \%$ trypsin-calcium chloride solution $\mathrm{pH} 7.8$ and incubated for 20 min at $37^{\circ} \mathrm{C}$. After a second rinse with PBS, rings were made around the tissue using a PAP pen (The Binding Site Inc, San Diego, CA, USA), to provide a boundary to hold small volumes of reagent to be added. Kidney sections were then incubated with a filtered solution $\left(100 \mu \mathrm{g} \mathrm{ml}^{-1}\right.$ in PBS) of acetone dried mouse liver (Sigma L-8254, St Louis, MO, USA) for $30 \mathrm{~min}$ in a moist chamber. The solution was poured off, and sections were then incubated with $30 \mu \mathrm{g} \mathrm{ml}^{-1}$ biotinylated GS-I lectin (Sigma L-3759, St Louis, MO, USA), for $1 \mathrm{~h}$ in a moist chamber. After 2 rinses in PBS, avidin-biotin peroxidase complex $A B C$ (Vector Lab., Burlingame, CA, USA) diluted in PBS (Sol. A $1 \mathrm{ug} \mathrm{ml}^{-1}$, Sol. B $2.5 \mu \mathrm{g}$ $\mathrm{ml}^{-1}$ ) was added. The $A B C$ was removed by 2 more rinses in PBS and the sections were then covered with a solution of $2 \mu \mathrm{g} \mathrm{ml}^{-1} 3,3^{\prime}$-diaminobenzidine tetrahydrochloride $(\mathrm{DAB})$ and $0.03 \%$ hydrogen peroxide, for 5 to 7 min. DAB was used as a chromogen-substrate because upon oxidation it forms a polymer that is brown and highly insoluble (Malik \& Daymon 1982, De Jong et al. 1985). The duration of the reaction and intensity of staining was monitored under the microscope, until the positive control showed well stained PKX. The reaction was stopped by flooding the slides with running tap water. The sections were then counterstained with Mayer's Hematoxylin for 3 to $5 \mathrm{~min}$, differentiated under tap water for $10 \mathrm{~min}$, dehydrated through an alcohol series and mounted in Pro-Texx (M-7635-1; American Scientific Products, USA) with a coverslip.

Monoclonal antibody immunohistochemistry. Tis sue sections were immunostained with monoclonal antibody against PKX according to Adams et al. (1992). Endogenous peroxide activity in deparaffinized kidney sections was blocked by incubation for $10 \mathrm{~min}$ in $10 \%$ hydrogen peroxide in methanol (Pearse-Everson 1980). After rinsing in Tris buffered saline (TBS, $0.05 \mathrm{M}$ Tris, $0.15 \mathrm{M} \mathrm{NaCl}, \mathrm{pH} \mathrm{7.6)}$, the sections were placed into 
moist chamber for $10 \mathrm{~min}$ with normal goat serum diluted $1: 10$ in TBS. The normal sera was decanted and undiluted supernatant from the Mab12 was added and after $1.5 \mathrm{~h}$ at $25^{\circ} \mathrm{C}$ it was removed by 3 rinses in TBS. Goat anti-mouse IgG conjugate with peroxidase (Sigma A-4416, St Louis, MO, USA) diluted 1:50 in TBS was added for $30 \mathrm{~min}$ at $25^{\circ} \mathrm{C}$. Excess conjugate was removed by washing in TBS and bound peroxidase was revealed by adding the chromogen $\mathrm{DAB}(0.3 \mu \mathrm{g}$ $\mathrm{ml}^{-1} \mathrm{DAB}, 0.02 \%$ hydrogen peroxide) for 3 to $7 \mathrm{~min}$. The reaction was stopped in running tap water, and the section counterstained using Mayer's hematoxylin or Prices's Giemsa (Luna 1968) and mounted in Pro-Texx with a coverslip.

Double labelling fluorescence method. Infected and uninfected paraffin-embedded kidney sections were deparaffinized in xylene and rehydrated in distilled water. The biotinylated GS-I lectin was diluted in $0.01 \mathrm{M}$ phosphate buffer $\mathrm{pH} 6.8$ (PBS) to provide dilutions of $25,10,5,1 \mu \mathrm{g} \mathrm{m} \mathrm{m}^{-1}$. Supernatant from the Mab12 hybridoma, either undiluted or diluted $1: 2$, was used to flood kidney sections for 1 to $2 \mathrm{~h}$ in a moist chamber. The slides were then rinsed 3 times in $0.01 \mathrm{M}$ phosphate buffer pH 8.0 containing $0.25 \%$ Tween-20 (PBST). Rhodamine-conjugated goat anti-mouse IgG (55527-Organon, Tecnika Corp., Durham, NC, USA) diluted 1:200 in PBS was added to the tissue, for 30 min. After 3 rinses in PBST, the slides were incubated for 1 to $2 \mathrm{~h}$ in a moist chamber with different dilutions of biotinylated lectin GS-I. After rinsing in PBST, the slides were incubated with 50 to $100 \mu \mathrm{l}$ of fluorescein avidin D (A-2001; Vector Laboratories, Inc., Burlingame, CA, USA), which was removed by rinsing before mounting in PBS pH 8.0 buffered glycerol with a coverslip. The sections were observed under a photomicroscope (Leitz Ortholux) equipped with a UV light source and excitation and barrier filters for both fluorescein and rhodamine. In subsequent trials, the same staining procedure was repeated but the sequences of incubations with lectin and Mab were reversed with biotinylated lectin and avidin-fluorescein followed by the Mab12. Positive controls included each procedure with only lectin or Mab12.

\section{RESULTS AND DISCUSSION}

The development of specific staining procedures for the detection of PKX have allowed a comparison of the myxosporean from diverse geographic regions and hosts. In addition, these stains provide further evidence that the sporogonic stages in the lumen of the kidney tubules, found most prominently in North American salmonids (Kent \& Hedrick 1985a, b, 1986, Hedrick et al. 1988) but also among certain European salmonids, share the same antigens and glycoconjugates as the well known extrasporogonic stage of PKX found in the kidney interstitium.

Histochemical and immunofluorescence staining procedures with GS-I and Mab12 detected extrasporogonic and sporogonic stages of the PKX myxosporean in all fish tested with the parasite regardless of their host species or geographical origin (Figs. 1 to 8 ) There were however, differences in the relative abundance of extrasporogonic and sporogonic stages between species and geographical regions. Extrasporogonic stages in the kidney interstitium of all salmonids tested were recognized by the GS-I lectin and Mab12 and these stages of the parasite and the pathology associated with their presence was similar to that originally described by Ferguson \& Needham (1978). One difference noted between species was an apparent predilection of the extrasporogonic stages (typical PKX interstitial stages) to be associated with thrombi in the larger veins of the kidney of chinook salmon (Fig. 4). This vascular affinity, known from rainbow trout as well (Clifton-Hadley et al. 1984, Smith et al. 1984), seems much more accentuated in juvenile chinook salmon with PKD (authors' obs.)

The initial phases of sporogenesis were characterized by PKX in the lumen of the tubules of Atlantic salmon (Fig. 1), Pacific salmon, and European brown trout (Fig. 2) and North American rainbow trout (Figs. 5 \& 6). These same stages were present but in a reduced prevalence and incidence among European rainbow trout (Fig. 3). Intraluminal pseudoplasmodia containing sporoblastic cells clearly indicating spore development (Fig. 5) as described by Kent \& Hedrick (1985a, 1986) were routinely encountered in rainbow trout from the American River and Hot Creek hatcheries in California, USA (Figs. 5 \& 6) and European Atlantic salmon and brown trout (Figs. $1 \& 2$ ). Counterstaining with Price's Giemsa allowed the observation of 2 spherical polar capsules in immature spores which also bound lectin or Mab12 (Fig. 6) within kidney tubules of North American rainbow trout and European brown trout with typical PKX in the interstitium. These sporogonic stages corresponded exactly to previous descriptions of the forms leading up to the most mature PKX spore observed to date (Kent \& Hedrick 1986, Hedrick et al. 1988). The abundance of these sporogonic stages in Atlantic salmon and brown trout compared to European rainbow trout with $\mathrm{PKD}$ has already been reported (Ferguson 1984, Clifton-Hadley \& Feist 1989).

The results of the staining with both monoclonal antibody and specific lectin provide the first evidence that PKX as found in different host species and from different continents share similar antigenic structures and glycoconjugates. The binding of these reagents to both extrasporogonic and sporogonic stages of the PKX 

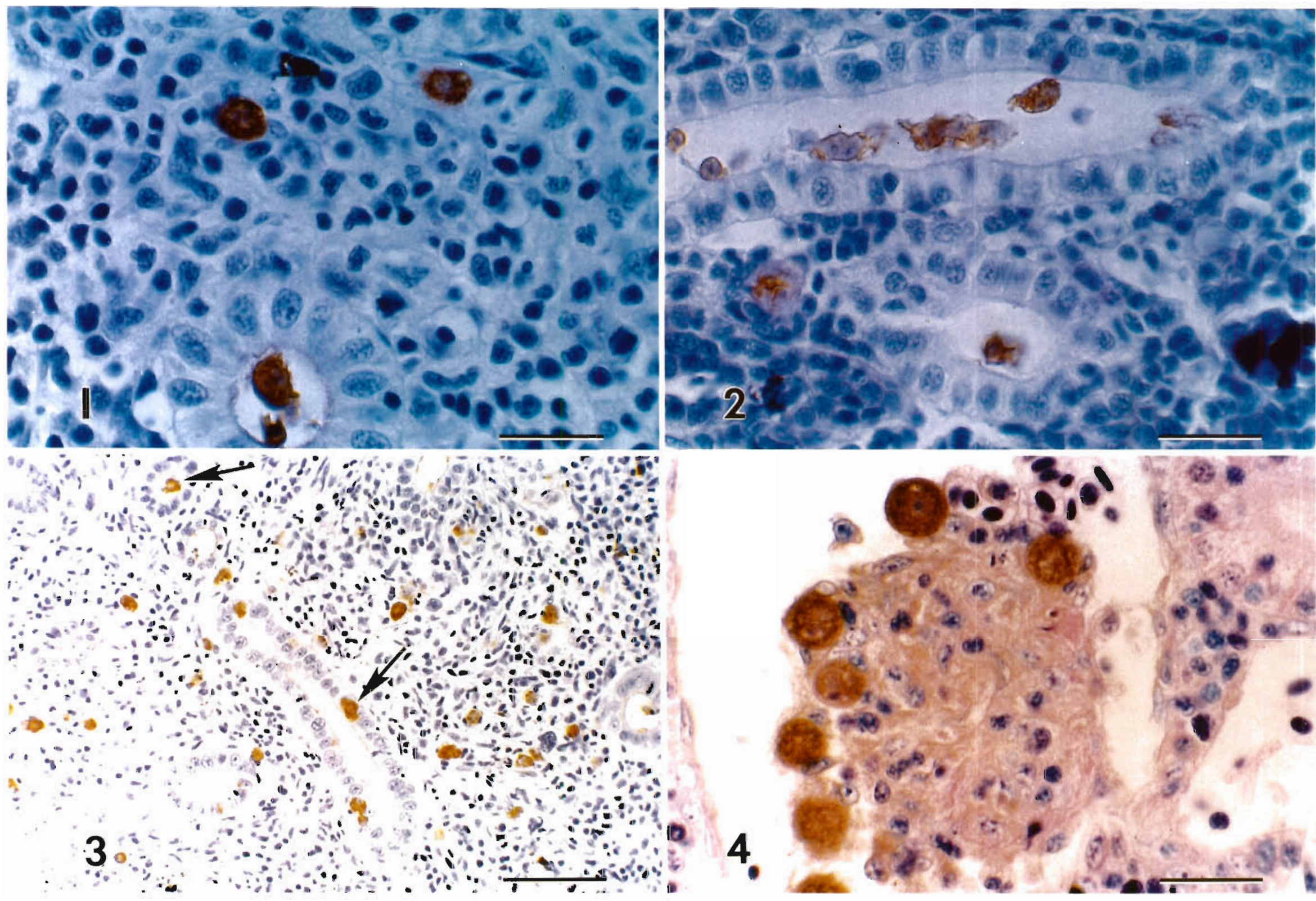
further supports the myxosporean etiology of the disease.

The binding site(s) for the monoclonal and lectin on PKX is currently unknown. However, both recognize features present on primary cells that are absent on daughter cells; an effect previously described for GS-I by Castagnaro et al. (1991). The patterns of binding for both the Mab12 and GS-I lectin were similar in double fluorescence stains (Figs. 7 \& 8) and they may even recognize the same dominant antigen (a glycoconjugate). This assumption is supported in part by an apparent inhibition between the binding of the lectin and Mab12. This inhibition is particularly evident when the biotinylated lectin precedes the antibody stain suggesting that the lectin either binds to, blocks, or induces a conformation change to the epitope recognized by Mab12. The GS-I lectin recognizes methyl- $\alpha$-D galactopyranosides and binds to glycoconjugates containing these residues on the PKX primary cell (Castagnaro et al. 1991). These prominent glycoconjugates may be the main antigenic sites recognized by the monoclonal but studies beyond the double staining procedures will be required to resolve the respective binding sites on the PKX cell for the lectin and monoclonal antibody. Colloidal gold techniques with the lectin and Mab12 should provide further insights into the nature of the structures recognized by each (Bartholomew et al. 1990, Bendayan 1984).

The application of lectin and monoclonal antibody staining procedures to a comparison of PKX from diverse hosts and geographical regions confirms a degree of antigenic homogeneity and further establishes the relationship of extrasporogonic and sporogonic stages of the PKX myxosporean. This makes these biologics useful for more rapid and specific diagnostic tests for the typical and less recognized sporogonic stages of the PKX myxosporean. The utility of the GS-I stain as a diagnostic tool was first demonstrated by Castagnaro et al. (1991) and the development of a more rapid fluorescence procedure (Hedrick et al. 1992) provides an excellent detection and confirmatory test for the PKX myxosporean. The Mab12 developed by Adams et al. (1992) provides yet another reagent with all of the advantages associated with an antibody probe. Additional applications of these reagents include isolation of antigens to detect
anti-PKX parasite antibodies in fish serum and the isolation of potential immunogens for vaccination of trout and salmon.

Acknowledgements. This work was supported in part by a FAR grant (No. AQ 1-30) from the EEC and Sport Fish Restoration Act Funds administered by the Calfornia Department of Fish and Game. M. Marin de Mateo was supported by a fellowship from the Ministerio de Educación y Ciéncia of Spain. Drs S. Feist and C. Ghittino are thanked for providing infected fish tissues for testing

\section{LITERATURE CITED}

Adams, A., Richards, R. H., Marin de Mateo, M. (1992). Development of monoclonal antibodies to PKX, the causative agent of proliferative kidney disease. J. Fish Dis. 15: $515-520$

Bartholomew, J. L., Yamamoto, T, Rohovec, J. S., Fryer, J, L. (1990). Immunohistochemical characterization of a monoclonal antibody against Ceratomyxa shasta. J. aquat. Anim. Hlth 2: 68-71

Bartholomew, J. L., Rohovec, J, S., Fryer, J. L. (1989). Development and characterization of monoclonal and polyclonal antibodies against the myxosporean, Ceratomyxa shasta. J. Protozool. 36: 397-401

Bendayan, M. (1984). Protein A- gold electron microscopic immunocytochemistry: methods, applications, and limitations. J. Electron. Microsc. Tech. 1: 243-270

Brown, J. A., Thonney, J. P., Holwell, D., Wilson, W. R. (1991). A comparison of the susceptibility of Salvelinus alpinus and Salmo salar ouananiche to proliferative kidney disease. Aquaculture 96: 1-6

Bucke, D., Feist, S. W., Clifton-Hadley, R. S. (1991). The occurrence of proliferative kidney disease (PKD) in cultured and wild fish: further investigations. J. Fish Dis. 14: $583-588$

Castagnaro, M., Marin, M., Ghittino, C., Hedrick, R. P. (1991). Lectin histochemistry and ultrastructure of the rainbow trout Oncorhynchus mykiss kidneys affected by proliferative kidney disease. Dis. aquat. Org. 10:173-183

Clifton-Hadley, R. S., Bucke, D., Richards, R. H. (1984). Proliferative kidney disease of salmonid fish: a review. J. Fish Dis. 7: $363-377$

Clifton-Hadley, R. S., Feist, S. W. (1989). Proliferative kidney disease in brown trout Salmo trutta: further evidence of a myxosporean aetiology. Dis. aquat. Org. 6: 99-103

Clifton-Hadley, R. S., Richards, R. H., Bucke, D. (1983) Method for the rapid diagnosis of proliferative kidney disease in salmonids. Vet. Rec. 112: 609

De Jong, A. S. H., van Kessel-van Vark, M., Raap. A. K. (1985). Sensitivity of various visualization methods for peroxidase and alkaline phosphatase activity in immunoenzyme histochemistry. Histochem. J. 17: 1119-1130

Figs. 1 to 4. Tissue sections from kidneys of salmonid fish with PKD. Fig. 1. Salmo salar. Section from Atlantic salmon immunostained with Mab12 (DAB $\mathrm{H}_{2} \mathrm{O}_{2}$ with Mayer's hematoxylin counterstainl detecting extrasporogonic (interstitium) and early sporogonic (intraluminal) stages of PKX. Scale bar $=25 \mu \mathrm{m}$. Fig. 2. Salmo trutta. Section from European brown trout immunostained with $\mathrm{Mab} 12\left(\mathrm{DAB} \mathrm{H}_{2} \mathrm{O}_{2}\right.$ with Mayer's hematoxylin counterstain); initial phases of sporogenesis in the lumen are recognised by this specific PKX monoclonal antibody. Scale bar $=25 \mu \mathrm{m}$. Fig. 3. Oncorhynchus mykiss. Section from European rainbow trout following histochemical staining with the lectin GS-I (DAB $\mathrm{H}_{2} \mathrm{O}_{2}$ and Mayer's hematoxylin counterstain). Specific detection of PKX present in the epithelium (lower arrow) and the lumen of renal tubule (upper arrow) and interstitial hemopoietic tissue. Scale bar $=60 \mu \mathrm{m}$. Fig. 4. Oncorhynchus tshawytscha. Section from Pacific salmon (chinook) immunostained with Mab12 (DAB $\mathrm{H}_{2} \mathrm{O}_{2}$ with Giemsa counterstain) demonstrating the vascular affinity of PKX and associated thrombi. Scale bar $=25$ um 


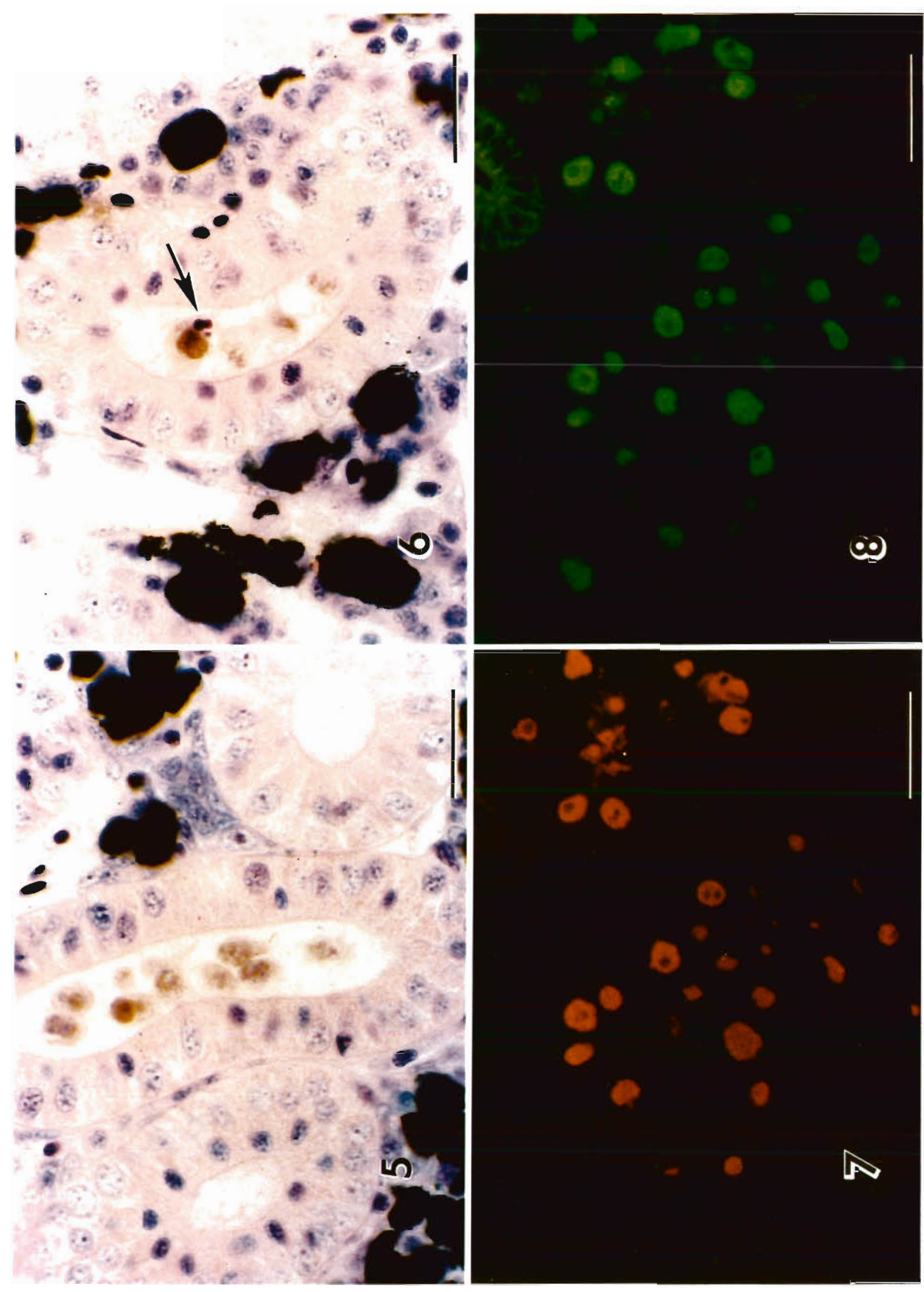


Ellis, A. E., McVicar, A. H., Munro, A. L. S. (1982). A preliminary report on the epidemiology of proliferative kidney disease in brown trout (Salmo trutta) and Atlantic salmon parr (S. salar) in Scotland. Bull. Eur. Ass. Fish Pathol. 2: 13-15

Feist, S. W., Bucke, D. (1987). Ultrastructural aspects of PKX, the causative agent of proliferative kidney disease in rainbow trout, Salmo gairdneri Richardson. J. Fish Dis. 10 $323-327$

Ferguson, H. W (1984). Proliferative kidney disease in Northern Ireland: epidemiology and control. S. F. Snieszko commerative workshop: Fish Health Sec., Am. Fish. Soc. A. conf., Little Rock, AR, p. 6

Ferguson, H. W., Needham, E. A. (1978). Proliferative kidney diseasse in rainbow trout, Salmo gairdneri Richardson. J. Fish Dis. 1. 91-108

Fischer-Scherl, T., El-Matbouli, M., Hoffmann, R. (1986). A new Sphaerospora sp. in brown trout (Salmo trutta $\mathrm{m}$. fariol in Germany. Bull. Eur Ass. Fish Pathol. 6: 16-19

Ghittino, P., Andruetto, S., Vigliani, E. (1977). L'amebiasi della trota iridea d'allevamento. Riv. ital. Piscic. Ittiopat. 12: 74-89

Hedrick, R. P., Kent, M. L., Foot, J. S., Rosemark, R., Manzer, D. (1985). Proliferative kidney disease PKD among salmonid fish in California USA. A second look. Bull. Eur Ass. Fish Pathol. 5: 36-38

Hedrick, R. P., Kent, M. L., Rosemark, R., Manzer, D. (1984a). Occurrence of proliferative kidney disease among Pacific salmonids and steelhead trout. Bull. Eur. Ass. Fish Pathol 4: $34-37$

Hedrick, R. P., Kent, M. L., Rosenmark, R., Manzer, D. (1984b). Proliferative kidney disease PKD in Pacific salmon and steelhead trout. J. Wld Maricult. Soc., 15: 318-325

Hedrick, R. P., Kent, M. L. Smith, C. E. (1986a). Proliferative kidney disease of salmonid fishes. Fish Dis. Leaflet 74, U.S. Dept of Interior, Fish and Wildlife Service, Washington, DC

Hedrick, R. P., Kent, M. L., Toth, R. J. (1986b). Myxosporeans detected in non-salmonid fishes from water enzootic for proliferative kidney disease (PKD). Bull. Eur Ass. Fish Pathol. 6: 32-35

Hedrick, R. P., Kent, M. L., Toth, R. J., Morrison, J. K. (1988). Fish infected with Sphaerospora spp. Thélohan (Myxosporea) from waters enzootic for proliferative kidney disease of salmonids. J. Protozool. 35: 13-18

Hedrick, R. P., Marin, M., Castagnaro, M., Monge, D., De Kinkelin, P. (1992). A rapid lectin-based procedure for the detection of the myxosporean causing proliferative kidney disease. Dis. aquat. Org. 13: 129-132

Hedrick, R. P., Monge, D., Kazanji, M., Marin, M., De Kinkelin, P. (1991). Recent development with proliferative kidney disease. Proc. OJI International Symposium on Salmonid Diseases. Hokkaido Press, Sapporo, p. $276-282$

Responsible Subject Editor: W. Körting, Hannover, Germany
Kent, M. L. (1985). The development of the PKX myxosporean, the causative agent of proliferative kıdney disease, in rainbow trout Salmo gairdneri Richardson. Ph.D. dissertation, Univ. California, Davis

Kent, M. L., Hedrick, R. P. (1985a). PKX, the causative agent of proliferative kidney disease (PKD) in Pacific salmonidfishes and its affinities with the Myxozoa. J. Protozool. 32 254-260

Kent, M. L., Hedrick, R. P. (1985b). Transmission of the causative agent of proliferative kidney disease (PKD) with the blood and spleen of infected fish; further evidence that the PKX parasite belongs to the phylum Myxozoa. Bull. Eur Ass. Fish Pathol. 5: 39-42

Kent, M. L., Hedrick, R. P. (1986). Development of the PKX myxosporean in rainbow trout Salmo gairdneri. Dis. aquat. Org. 1: 169-182

Klontz, G. W., Chacko, A. J. (1983). Methods to detect the organism causing proliferative kidney disease in salmonids. Bull. Eur. Ass. Fish Pathol. 3: 33-36

Luna, L. G. (1968). Manual of histologic staining. McGrawHill, New York

Maddox, P. H., Jenkins, D. (1987). 3-Aminopropyltriethoxylane (APES): a new advance in section adhesion. J. clin. Pathol. 40: 1256-1260

Malik, N. J., Daymon, M. E. (1982). Improved double immunoenzyme labelling using alkaline phosphatase and horseradish peroxidase. J. clin. Pathol. 35: 1092-1094

Marin de Mateo, M., Ghittino, C., Castagnaro, C. (1991). Dimostrazione dell'agente eziologico della PKD (Proliferative Kidney Diseasel nella trota iridea mediante la tecnica istochimica delle lectıne: Nota preliminare. Boll. Soc. ital. Patol. Ittica. 5: 62-67

Pearse-Everson, A. G. (1980). Histochemistry. Theoretical and applied, Vol. I. Churchill Livingstone, Edinburgh

Rafferty, M. D., Mulcahy, M. F. (1988). Is PK'X' related to Sphaerospora? Bull. Eur. Ass. Fish Pathol. 8: 47

Roberts, R. J. (1978). Fish pathology. 1st edn. Bailliere Tindall, London

Seagrave, C. P., Bucke, D., Hudson, E. B., McGregor, D (1981). A survey of the prevalence and distribution of proliferative kidney disease (PKD) in England and Wales J. Fish Dis. 4: 437-439

Smith, C. E., Morrison, J. K., Ramsey, H. W., Ferguson, H. W (1984). Proliferative kidney disease: first reported outbreak in North America. J. Fish Dis. 7: 207-216

von Odening, K., Walter, G., Bockhardt, I. (1988). Koinzidentes Auftreten von PKX und Sphaerospora sp. (Myxosporidia) in Beständen von Salmo gairdneri (Osteichthyes). Angew. Parasit. 29: 137-148

Wootten, R., McVicar, A. H. (1982). Some preliminary observations on proliferative kidney disease in wild brown trout, Salmo trutta L., in a Scottish stream. Bull. Eur. Ass. Fish Pathol. 2: 60-62

Manuscript first received: August 24, 1992

Revised version accepted: September 29, 1992

Figs. 5 to 8. Oncorhynchus mykiss. Tissue sections from the kidney of North American rainbow trout with PKD. Fig. 5. Section immunostained with $\mathrm{Mab} 12$ (DAB $\mathrm{H}_{2} \mathrm{O}_{2}$ with Giemsa counterstain). Showing intraluminal pseudoplasmodia recognized by the PKX monoclonal antibody. Scale bar $=25 \mu \mathrm{m}$. Fig. 6. Section immunostained with Mab12 (DAB $\mathrm{H}_{2} \mathrm{O}_{2}$ with Giemsa counterstain) with an immature PKX spore in the lumen of a tubule. Monoclonal antibody binds to the intraluminal pseudoplasmodium containing 2 spherical dark blue polar capsules (arrow). Scale bar $=25 \mu \mathrm{m}$. Fig. 7 . Section stained with Mab12 with rhodaminelabelled goat anti-mouse lgG in a double fluorescence test. Scale bar $=60 \mathrm{\mu m}$. Fig. 8 . Section stained with biotinylated GS-[ lectin with avidin fluorescein $\mathrm{D}$ in a double fluorescence test. Scale bar $=60 \mu \mathrm{m}$ 